\title{
Taxation as a Source of Revenue Generation in Local Governments, Nigeria
}

\author{
Osho, Augustine E. Ph.D \\ Department of Accounting, Achievers University, P. M. B. 1030, Owo, Nigeria \\ Ajayi, David Adelagun. \\ Directorate of Internal Audit, Rufus Giwa Polytechnic, P. M. B. 1019, Owo, Nigeria \\ Ogunbodede, Rachel Olufunke \\ Bursary Department, Rufus Giwa Polytechnic, P. M. B. 1019, Owo, Nigeria
}

\begin{abstract}
This paper examined Taxation as Source of Revenue Generation in Local Governments, Nigeria which covers a period of 5years (2013-2017). The researchers' adopted a descriptive and empirical case study approach using secondary data. Findings revealed that some of the potential sources of revenue are completely neglected by the local government authority and also finds out that civil servants constitute the highest source of tax revenue in form of PAYE to the local government. Also, it shows that taxation in no doubt have impacted the economic development of Nigeria in general. Based on this study, it is recommended that periodical training of tax officials should be introduce by the government to maintain high generation of tax revenue and the system deserves autonomy that will enable it to hire the right quality of staff and equipment that it deserves to make it function effectively.
\end{abstract}

Keywords: Revenue, Taxation, Voluntary Assets and Income Declaration Scheme (VAIDS)

DOI: $10.7176 /$ RJFA/10-6-04

Publication date:March $31^{\text {st }} 2019$

\subsection{Introduction}

Taxation is the most important source of revenue to the three tiers of government in Nigeria. The needs for state and local governments to generate adequate revenue from internal sources have therefore become a matter of extreme urgency and importance Afuberoh \& Okoye (2014). They further explained that this need underscores the eagerness on the part of state and local governments and even the Federal government to look for new sources of revenue or mode of collecting revenue from existing sources. Aguolu, (2004), states that though taxation may not be the most important source of revenue to the government in terms of magnitude of revenue derivable from taxation, however, taxation is the most important source of revenue to the government, from the point of view of certainty and consistency of taxation. Taxation is a way of raising revenue for the day to day running of government activities involves generating funds and using same to provide security, social amenities, infrastructural facilities, etc. for the inhabitant of the country. Base on this, it is worthy of note that the objective of taxation is in tandem with the functions of government (Akhor, 2014).

In Nigeria, revenues have been allocated according to the formulae recommended by Ad-hoc fiscal commissions or based on a principle chosen by the state. Each commission recommended a formula for revenue sharing depending on the economic fortunes and purposes, which the government wanted the revenue sharing formula to serve. More so, the revenues are raised mainly through taxation to finance government expenditure and to influence other activities in the economy (Taiwo, 2008). In addition, tax revenue mobilization as a source of financing developmental activities in less developed economies has been a difficult issue primarily because of various form of resistance, such as evasion, avoidance and other corrupt practices can easily be perpetuated within the direct taxes bracket. These activities are considered as sabotaging the economy and are readily presented as reasons for the underdevelopment of the country.

Presently, in Nigeria, there is a scheme introduced by the federal government for tax defaulters (Tax evaders and Tax avoiders) to regularize their tax status relating to previous tax periods. The scheme is known as Voluntary Assets and Income Declaration Scheme (VAIDS).

Revenue has been defined by various scholars at different times. It lacks universal accepted definition. According to Procter (2005) revenue is an income. Fayemi (2001) sees it as all tolls, taxes, impress, rates, fees, duties, fine, penalties, fortunes and all other receipt of government from whatever source arising over a period either one year or six months.

Recently, the revenue that accrues to state government is derived from two broad sources, viz; the external and the internal sources. The increasing cost of running government coupled with dwindling revenue has left various state governments in Nigeria with formulating strategies to improve the revenue base. More so, the near collapse of the national Economy has created serious financial stress for all tiers of government. Hardest hit are 
the state governments all of whom have experienced unusual reduction in their share of the national revenue from the federal account. Despite the numerous sources of revenue available to the various tiers of government as specified in Nigeria 1999 constitution, since the 1970s till now, over $80 \%$ of the annual revenue of the three tiers of government come from petroleum. However, the serious decline in the price of oil in recent years has led to decrease in the funds available for distribution to the States. The need for state and local governments to generate adequate revenue from internal sources has become a matter of extreme urgency and importance.

The Federal government, under ministry of finance has trained and deployed some community tax liaison officers to work with Federal Inland Revenue Service (FIRS) and all State Board of Internal Revenue Services in all states within Nigeria to help the federal government in regard of the newly introduced Scheme (VAIDS).

Revenue generation in Nigeria is principally derived from tax which is a necessary ingredient for civilization. Tax is a compulsory levy imposed by government on individuals and companies for the various legitimate function of the state (Olaoye, 2008). No system or rules can be effective whether foreign or nature unless it enjoys some measures of financial independence.

Over the years, revenue derived from taxes has been very low and no physical development actually took place, hence the impact on the poor is not being felt. Inadequate tax personnel, fraudulent activities of tax collectors and lack of understanding of the importance to pay tax by tax payers are some of the problems of this study. These issues therefore constitute the problem to be addressed by this research work.

\subsection{Literature Review \\ 2.1 Concept of Taxation}

Tax is a compulsory levy imposed by government on individuals, companies, for the various legitimate functions of the state. All levels of governments in Nigeria do no longer perform the responsibilities simply because of financial crisis experienced form internally generating revenue. This bad financial situation is further aggravated by the prevailing inflationary situation in this country which erodes the value of funds available to render essential social service to the people. Okafor (2012) advocated the use of tax as an instrument of social engineering, to stimulate general and/or sectorial economic and the government.

Taxation is not a new word in Nigeria or the world as a whole. In Nigeria, taxation has been in existence even before the coming of colonial men or the British. Taxation can be defined as the system of imposing a compulsory levy on all income, goods, services and properties of individuals, partnership, trustees, executorship and companies by the government (Samuel \& Simon, 2011). Income tax is one of the major sources of revenue to all government in Nigeria, it is a factor to be reckoned with in Federal government's budget and the taxes so collected come back to tax payer in form of services. In Nigeria, tax revenue has accounted for a small proportion of total government revenue over the years because the bulk of revenue needed for development purposes is derived from oil.

The main aim of any developing nation like Nigeria is to increase the rate of economic growth and per capital income which otherwise increases the standard of living thus taxation can be used as a stimulus to accelerate such growth. Azubuike (2009) posits that tax is a major player in every society of the world. It is an opportunity for government to generate additional revenue to discharge its pressing Obligations. Also, it is one of the effective means of mobilizing a country's internal resources so as to promote economic growth.

Taxation is a way of raising revenue for the day to day running of government activities. Government activities involve generating funds and using same to provide security, social amenities, infrastructural facilities, etc, for the inhabitant of the country. Base on this, it is worthy of note that the objective of taxation is in tandem with the functions of government (Akhor, 2014). However, over the years, it has been observed that the Nigerian tax system has inherent problems in its structure. Odusola (2006) opined that the Nigerian tax system is concentrated on Petroleum Profit Tax (PPT) and Company Income Tax (CIT) while broad-based indirect taxes like the Value-Added Tax (VAT) and Custom and Excise Duty (CEXD) are neglected. Thus, the tax system lacks the potential of diversifying the revenue portfolio for the country to safeguard against the volatility of crude oil prices and to promote fiscal sustainability and economic viability at lower tiers of government (Azaiki \& Shagari, 2007).

Government collects taxes in order to provide an efficient and steadily expanding non-revenue yielding services, such as infrastructure, education, health, communications system, employment opportunities and essential public services like the maintenance of laws and order, irrespective of the prevailing ideology or the political system of a particular nation. The very act of taxation has profoundly beneficial effects in fostering better and more accountable government (Tax Justice Network [TJN], (2012).

Taxation in Nigeria following the extant laws is enforced by the 3 tiers of government, that is, federal, state, and local governments with each having its sphere clearly spelt out in the Taxes and Levies (approved list for collection) Decree, 1998. However, Nigeria runs a largely centralized revenue collection system, with the federal government collecting the major revenue (petroleum revenue - profit taxes, royalties, crude oil sales; company income tax, value added tax, customs and excise duties) on behalf of the constituent governments (Emmanuel, 
2010).

Revenue from taxes remains the most significant contributor to nation's fiscal and economic development (IMF, 2007 as cited by Fasina, 2014). The relevance of revenue from taxation is a core motive for increased suggestion that emerging economies such as Nigeria must increase resources from within for sustained economic growth and fiscal deficit reduction through effective tax policy (Wawive, 2006). The main consequence of the persistent volatility in the world market price of crude oil which remains as the main source of revenue into Nigeria federation account result in persistent decline collectable revenue, hence, the need to empirically investigate the government revenue profile (Fasina, 2014).

\subsection{Tax Structure in Nigeria}

A good tax structure plays a multiple role in the process of economic development of any nation including Nigeria (Appah, 2010). According to the national tax policy, a tax is usually a monetary charge on a person's or entity's income, property or transaction and is usually collected by a defined authority at the federal and state level. Taxes maybe direct or indirect and may be imposed on individual basis, on entities, on assets and on transaction's basis.

In Nigeria, taxes are imposed on the following bases (according to national tax policy):

\section{On Individuals}

(i) Personal Income tax - imposed on the income of all Nigeria citizens or residents who derive income in Nigeria and outside Nigeria.

(ii) Development levy - a flat charge imposed on every taxable person typically within a state.

\section{On Companies (Corporate Entities)}

(i) Company Income tax - Imposed on the profits of all corporate entities who are registered in Nigeria or derive income from Nigeria, other than those engaged in petroleum operations.

(ii) Petroleum profit tax - Imposed on the profits of all corporate entities registered in Nigeria or who derive income from oil and gas operations in Nigeria.

(iii) Education Tax - Imposed on all corporate entities registered in Nigeria.

(iv) Technology Levy - imposed on selected entities (telecommunication companies, internal service providers, pension managers, banks, insurance companies and other financial institutions within a specified turn over range in Nigeria to support nationwide development of technology

\section{On Transactions} infrastructure and capacity.

(i) Value Added Tax - Imposed on the net sales value of non - exempt, qualifying goods and services in Nigeria.

(ii) Capital Gain Tax - Imposed on capital gain derived from sale or disposal of chargeable assets

(iii) Stamp duty - imposed on instrument executed by individual and corporate entities in Nigeria.

(iv) Excise duty - Imposed on the manufacture of goods within the government territory collected by the Nigeria custom service.

(v) Import duty - imposed on the import of goods into the government territory collected by the Nigeria custom service.

(vi) Export duty - Imposed on the export of goods outside the government territory collected by the Nigeria custom service.

\section{On Assets}

This includes taxes, such as property tax and other such taxes imposed on land or landed property.

\subsubsection{The Role of Taxation in Wealth Creation and Employment}

According to Nzotta (2007), four key issues must be understood for taxation to play its functions in the society.

(i) Tax is a compulsory contribution made by the citizens to the government and this contribution is for general common use.

(ii) Tax imposes a general obligation on the tax payer.

(iii) There is a presumption that the contribution to the public revenue made by the tax payer may not be equivalent to the benefits received.

(iv) Tax is not imposed on a citizen by the government because it has rendered specific services to him or his family.

Taxation can play a vital and pivotal role in the creation of wealth and employment in Nigeria economy in the following ways (national tax policy):

(i) Stimulating growth in the economy, by increased trade and economic activities; In this regard, tax revenues should be used to provide basic infrastructure such as power, roads transportation and other infrastructure which would facilitate trade and other economic activities.

(ii) Stimulating domestic and foreign investment: where the tax system creates a competitive edge for investments. In the economy, local investment would generate employment and provide wealth in 
the hands of individuals.

(iii) Revenue generated from taxes can also be applied directly to identify sectors of the Nigerian economy to stimulate such sectors. In this regard, the sectors must be those which have potential for creating employment, developing the economy and creating wealth for the greater benefit of citizens and government of this country.

(iv) Revenue earned from taxes can be used to develop effective regulatory systems, strengthen financial and economic structures and address market imperfections and other distortions in the economic sector. Taxes realized from specific sectors of the economy can be channeled back to these sectors to encourage their growth and development.

(v) Redistribution of income, where by tax revenue realized from high income earners is used to provide public infrastructure and utilities to the lowest income earners. Taxes may also be used to create a social security net for short and long terms reliefs to indigent members of society and other classes of persons who may require such intervention by the government. (National tax policy).

\subsubsection{Voluntary Assets and Income Declaration Scheme (VAIDS) in Nigeria}

Nigeria's tax system is based on global best practice. It is a progressive system that ensures fairness. Those with highest income levels should shoulder the greatest proportion of the tax burden. Whilst considerable progress has been made with taxing those in formal employment, self - employed persons, professional and some companies are able to evade full tax payment due to the inability of the tax authorities to assess their true income and there by tax them accurately (VAIDS CTLOs Study Pack). According to the joint tax board (JTB), as at May 2017 the total number of tax payers in Nigeria is just 14 million out of an estimated 69.9 million who are economically active.

Nigeria's tax to GDP ratio, at just 6 per cent, is one of the lowest in the world (compared to India's of 16 per cent, Ghana 15.9 per cent and South Africa's of 27 per cent). Most developed Nations have tax to GDP ratios of between 32 per cent and 35 per cent.

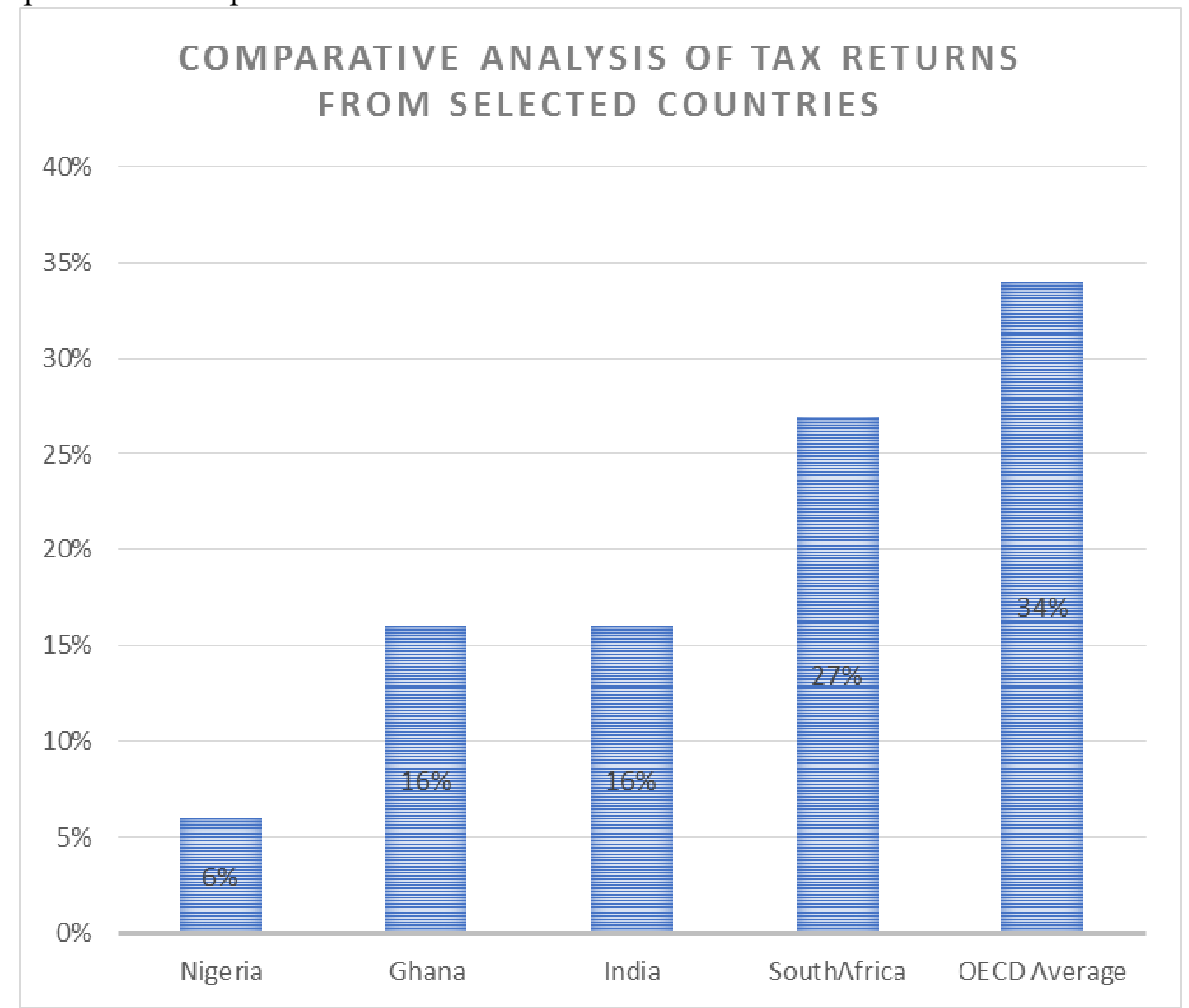

Source: VAIDS CTLO Study Pack (2017)

The above bar chart representation denotes that Nigeria has a very low tax returns ( 6 per cent) compared with some other countries in the world. The Organization for Economic Co-operation and Development (OECD) has an average percentage of 34 per cent, which is far above the position of Nigeria. Even, Ghana (a fellow West African nation) with 16 per cent and South Africa (a fellow African country) with 27 per cent tax returns fair better than Nigeria.

Voluntary Asset and Income Declaration Scheme is a time limited opportunity for the tax payers to 
regularize their tax status relating to previous tax periods. In exchange for fully and honesty declaring previously undisclosed asset and income, tax payers will benefit from forgiveness of overdue interest and penalties and the assurance that will not face criminal prosecution for tax offences or be subject to tax investigations (VAIDS CTLOs Study Pack, 2017). VAIDS ushers in an opportunity to increase the nation's general tax awareness and compliance. Some of the ways in which taxes are evaded include:

- Manipulating accounting records by keeping two sets of books.

- Many states have lacked the machinery to accurately track the true income of their residents.

- Use of complex structures in transactions to evade taxes.

- Non-registration for VAT or changing of VAT without remitting to FIRS.

- None payment of Capital Gain Tax (CGT) on asset disposals.

Nigeria's low tax revenues are variance with the lifestyles of a large number of its people and with the value of assets known to be owned by Nigeria's resident around the world. In addition despite having some of the most profitable and well capitalized companies in Africa, the level of tax remittance is low.

\subsubsection{Theoretical Review}

The researchers' has used two theories related to the research work which are; Prof. Arthur Laffer Theory and Ibn Khaldrun Theory.

\subsubsection{Prof Arthur Laffer Theory}

The first theory that this study looks at is Prof. Arthur Laffer theory on taxation, popularly known as the "Laffer curve". It is a theoretical representation of the relationship between government revenue raised by taxation and all possible rates of taxation.

This theory is demonstrated with a curve (i.e. Laffer curve which is constructed by through experiment).

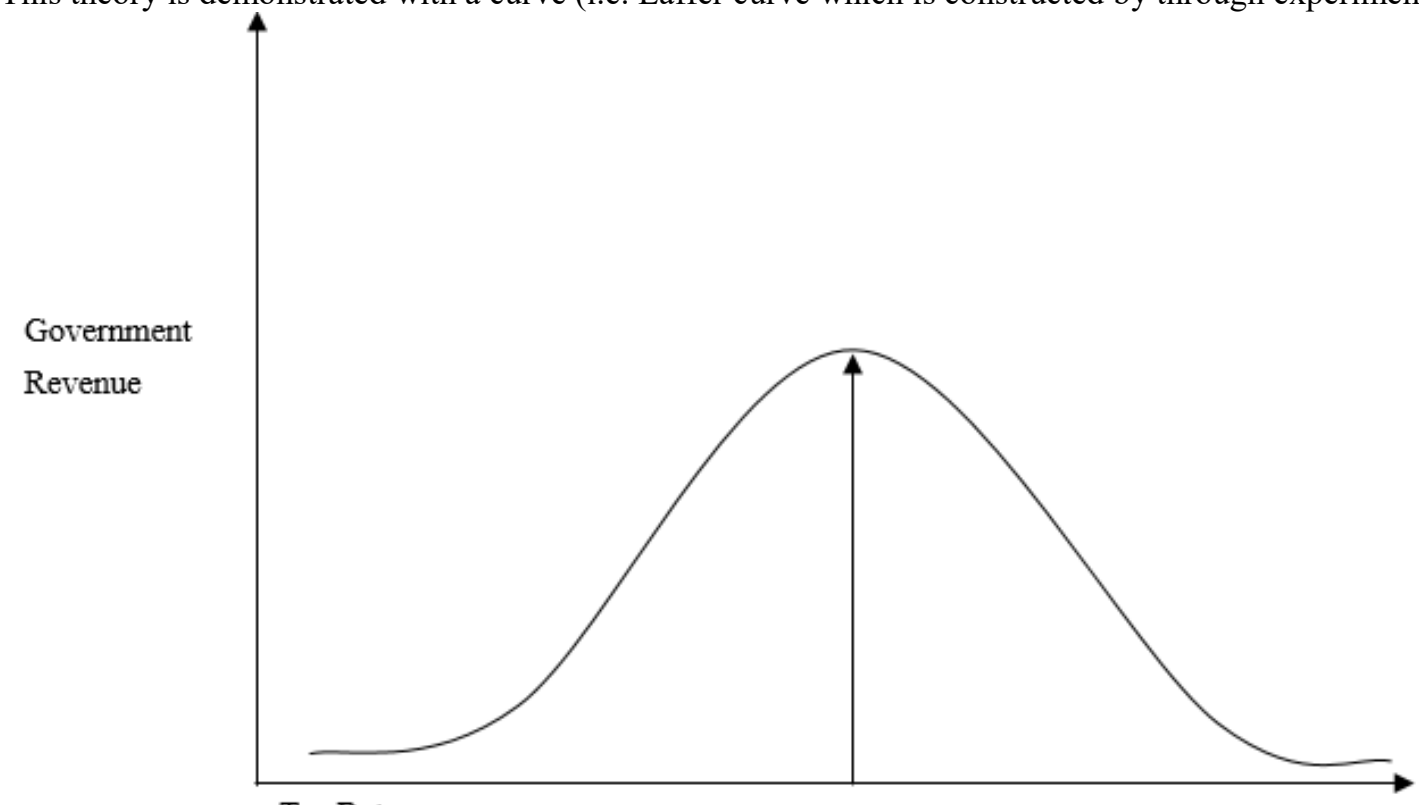

Tax Rate

Fig. 2 Source: Laffer Curve (2004)

It considered the amount of tax revenue raised at the extreme tax rates of 0 percent and 100 per cent. The theory concludes that a 100 per cent tax rate raises no revenue in the same way that a 0 per cent rate raises no revenue. This is because at 100 per cent rate, there is no longer incentive for a rational tax payer to earn any income, thus, the revenue raised will be 100 per cent of nothing. It therefore follows that there must exist at least one rate in between where tax revenue would be a maximum. Larger attributes the concept of Ibn Khaldrun and Keynes J.M.

\subsubsection{Ibn Khaldum Theory}

The second theory that helps to shape taxation is Ibn Khaldrun theory on taxation. This theory was explained in term of two different effects that is the arithmetic effect and the economic effect which the tax rates have on revenues (Islahi, 2006). The two effects have opposite results on revenue in case the rates are increased or decreased.

According to the arithmetic effect, if tax rates are lowered, tax revenues will be lowered by the amount of the decrease in the rate. The reverse is true for an increase in tax rates. The economic effect however recognized the positive impact that lower tax rate have on work, output and employment and thereby the tax rate base used in providing incentives to increase these activities whereas raising tax rates here the opposite economic effect is used by penalizing participation in the taxed activities. At a very high tax rate, negative economic effect 
dominates positive arithmetic effect, thereby, the tax revenue declines (Islahi, 2006).

2.2.3 Conceptual Framework of Taxation as a Source of Revenue Generation in Local Governments, Nigeria

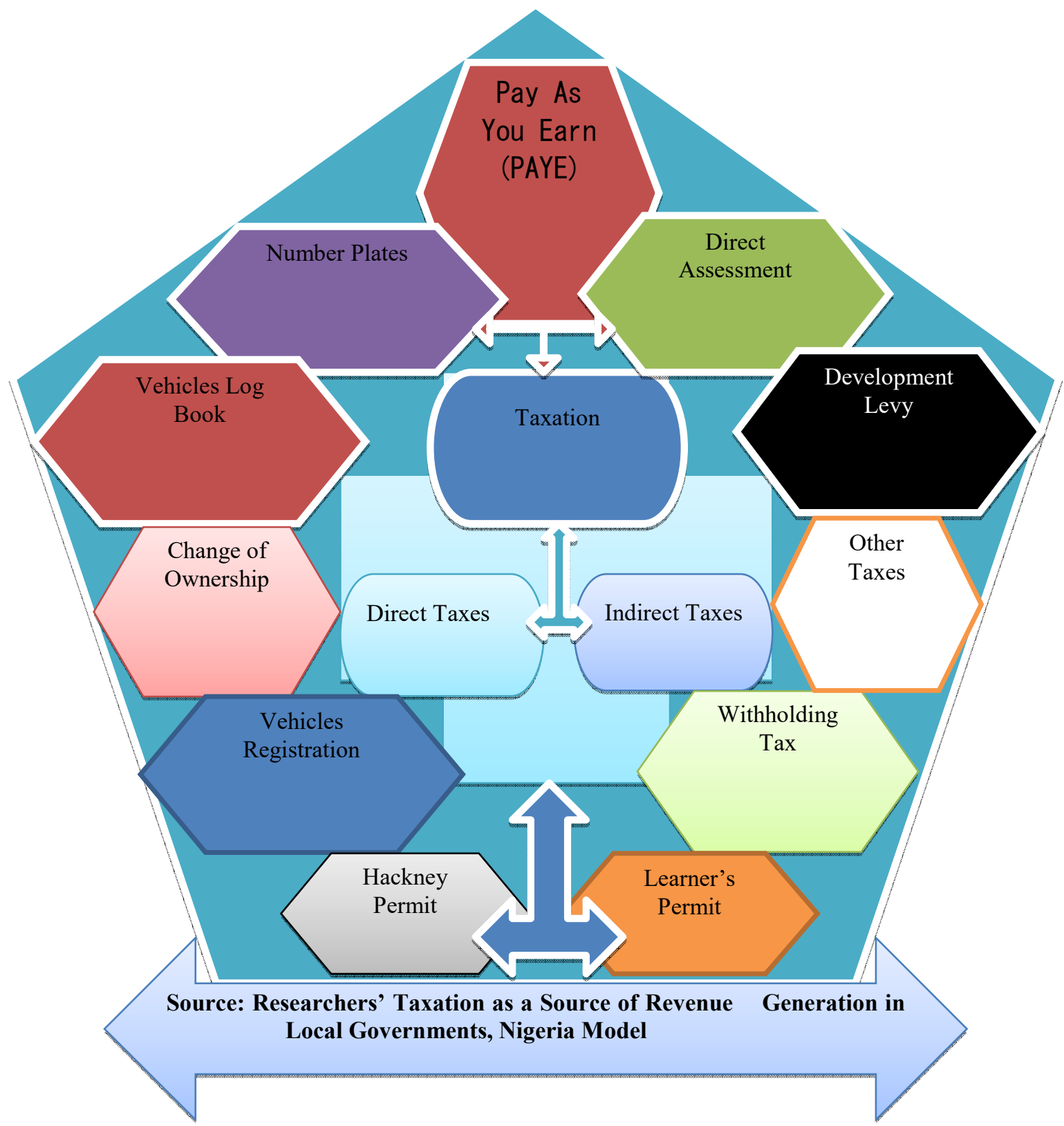

\subsection{Methodology}

The research adopted a descriptive and empirical case study approach using secondary data. The available annual data on the ten variables is limited to a five-year period spanning 2013 to 2017 on ten sources of collectable taxes which includes PAYE, direct assessment, development levy, withholding tax, learner's permit, hackney permit, vehicles registration, change of ownership, vehicle log book and number plates respectively with the use of convenience sampling, which is a non-probability sampling technique, for collection of data. The study employed modes, dispersion and measures of central tendency through descriptive statistics, correlation analysis, $t$-tests and graphs. The tools used in the study are therefore robust enough to achieve the objectives of the stud 


\subsection{Results}

Table 4.1: Descriptive Statistics Output CHOWNER DASS DEVLEVYHACKPMTLEARPMT LOGB NUMPT PAYE VEHREG VELICE WITHTAX TOTAL

$\begin{array}{lcccccccccccc}\text { Mean } & 0.378400 & 22.44000 & 0.440400 & 0.726000 & 0.127600 & 0.193800 & 6.570000 & 84.99400 & 0.612000 & .558600 & 24.85800 & 143.8106 \\ \text { Median } & 0.082000 & 21.44000 & 0.260000 & 0.320000 & 0.029000 & 0.190000 & 5.270000 & 63.33000 & 0.340000 & 3.050000 & 3.630000 & 101.9960 \\ \text { Maximum } & 1.530000 & 25.16000 & 0.990000 & 2.550000 & 0.490000 & 0.430000 & 11.61000 & 170.5100 & 1.570000 & 3.580000 & 112.1300 & 323.1850 \\ \text { Minimum } & 0.065000 & 20.08000 & 0.132000 & 0.170000 & 0.020000 & 0.061000 & 2.590000 & 20.76000 & 0.260000 & 0.023000 & 0.000000 & 49.96600 \\ \text { Std. Dev. } & 0.644426 & 2.487609 & 0.360473 & 1.021631 & 0.203736 & 0.145493 & 3.757685 & 66.93682 & 0.556749 & 1.449591 & 48.87882 & 112.4259 \\ \text { Skewness } & 1.492406 & 0.294178 & 0.732240 & 1.485296 & 1.459459 & 0.875924 & 0.356386 & 0.329567 & 1.250146 & -1.339001 & 1.486020 & 0.865521 \\ \text { Kurtosis } & 3.239537 & 1.217937 & 1.956772 & 3.231004 & 3.191528 & 2.475001 & 1.554160 & 1.382425 & 2.857177 & 3.035954 & 3.230898 & 2.268319 \\ \text { Jarque-Bera } & 1.868016 & 0.733731 & 0.673548 & 1.849536 & 1.782659 & 0.696791 & 0.541353 & 0.635627 & 1.306637 & 1.494373 & 1.851320 & 0.735805 \\ \text { Probability } & 0.392976 & 0.692903 & 0.714070 & 0.396623 & 0.410110 & 0.705820 & 0.762863 & 0.727739 & 0.520316 & 0.473698 & 0.396270 & 0.692185 \\ \text { Sum } & 1.892000 & 112.2000 & 2.202000 & 3.630000 & 0.638000 & 0.969000 & 32.85000 & 424.9700 & 3.060000 & 12.79300 & 124.2900 & 719.0530 \\ \text { Sum Sq. Dev. } & 1.661141 & 24.75280 & 0.519763 & 4.174920 & 0.166033 & 0.084673 & 56.48080 & 17922.15 & 1.239880 & 8.405259 & 9556.555 & 50558.33 \\ \text { Observations } & 5 & 5 & 5 & 5 & 5 & 5 & 5 & 5 & 5 & 5 & 5 & 5\end{array}$

\section{Source: Researchers' Descriptive Statistics Output computation}

As shown in Table 4.1, the average total internally revenue generated (IGR) through taxation by a Local Government for the five-year period under consideration was about $\$ 144$ million and this number reached a maximum of about $\$ 323$ million with a minimum of about $\$ 50$ million. Of all the IGRs, PAYE holds the highest average with a value amounting to about $\$ 90$ million, which reached a maximum value of $\$ 170.5$ million and a minimum value of $\$ 21$ million. This is followed by Withholding Tax with a maximum value of \#25 million, a maximum value of $\$ 12$ million but a minimum value of 0 naira. This statistic suggests that there was no proper record kept for this variable in that year, as it is impracticable to generate zero revenue from that variable in a year. Direct assessment records the third largest source of revenue via taxation to the local government with an average value of 22.44 million, a minimum value of 20.08 million and a maximum value of 25.16. Learners' Permit records the lowest source of revenue via taxation in the local government with an average value of $\$ 39000$ reaching a maximum value of $\$ 494,500$ and a minimum value of $\$ 20,000$.

\subsection{Pattern of Occurrence of the Variables}
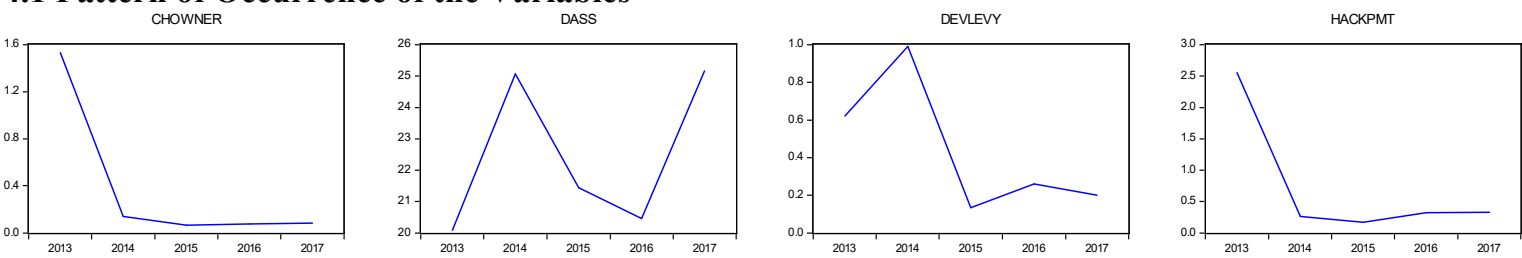

LEARPMT

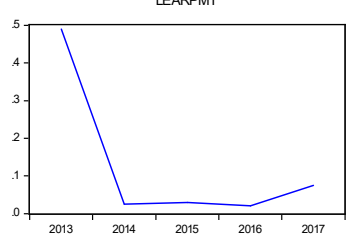

LOGB

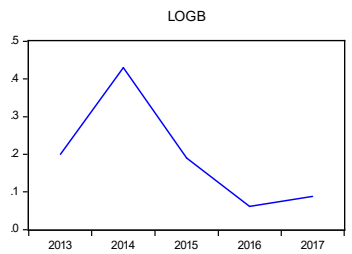

NUMPT

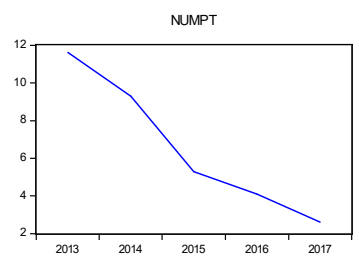

PAY

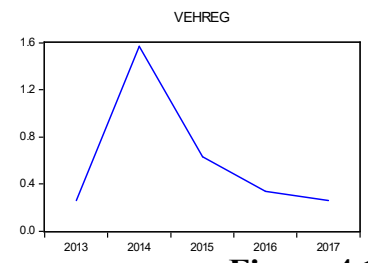

VEUCE
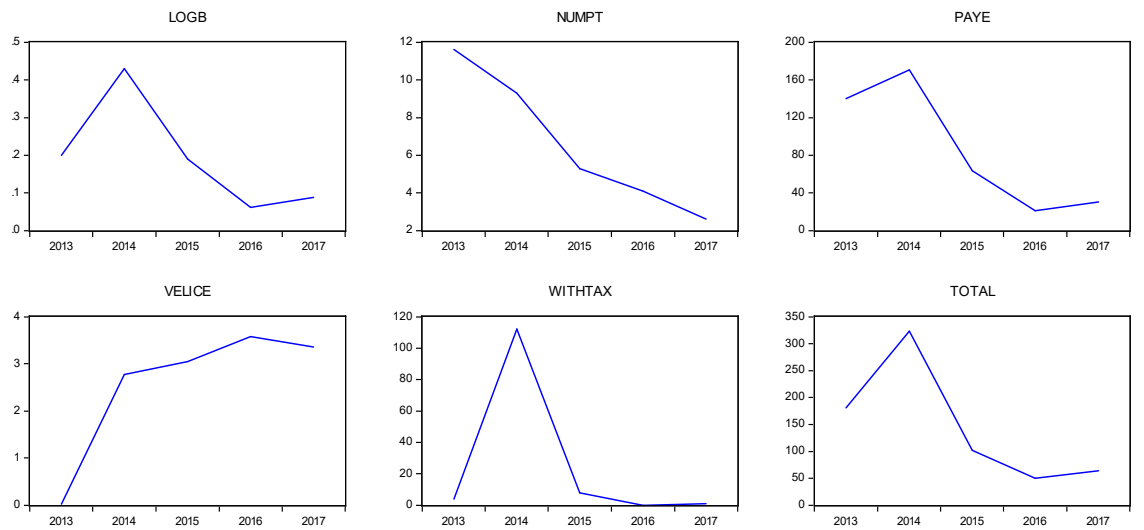

Figure 4.1: Multiple Graphs showing a Visual Representation of the Variables Source: Researchers' Computation

\subsection{Discussion}

\section{Pay As You Earn}

This constitutes the highest source of tax revenue to the local government over the period of study. However, there is notable inconsistent pattern of maintaining its generation as a veritable source of revenue. It is shown in Figure 4.2 and corroborated by Figure 4.1; the variable increased from about $\$ 140$ million in 2013 to above $\$ 170$ million in 2014 , but decreased sharply to about $\$ 63$ million in 2015 , decreasing further to a paltry sum of $\$ 20.7$ million in 2016 and a marginal increase to $\$ 30.3$ million in 2017 . This gory development might be as a result of inconsistent pattern of salary payment to the civil servants which was in the last three years. A situation where several months' salary is owed workers clearly affects the internally generated revenue accruable to the government. 


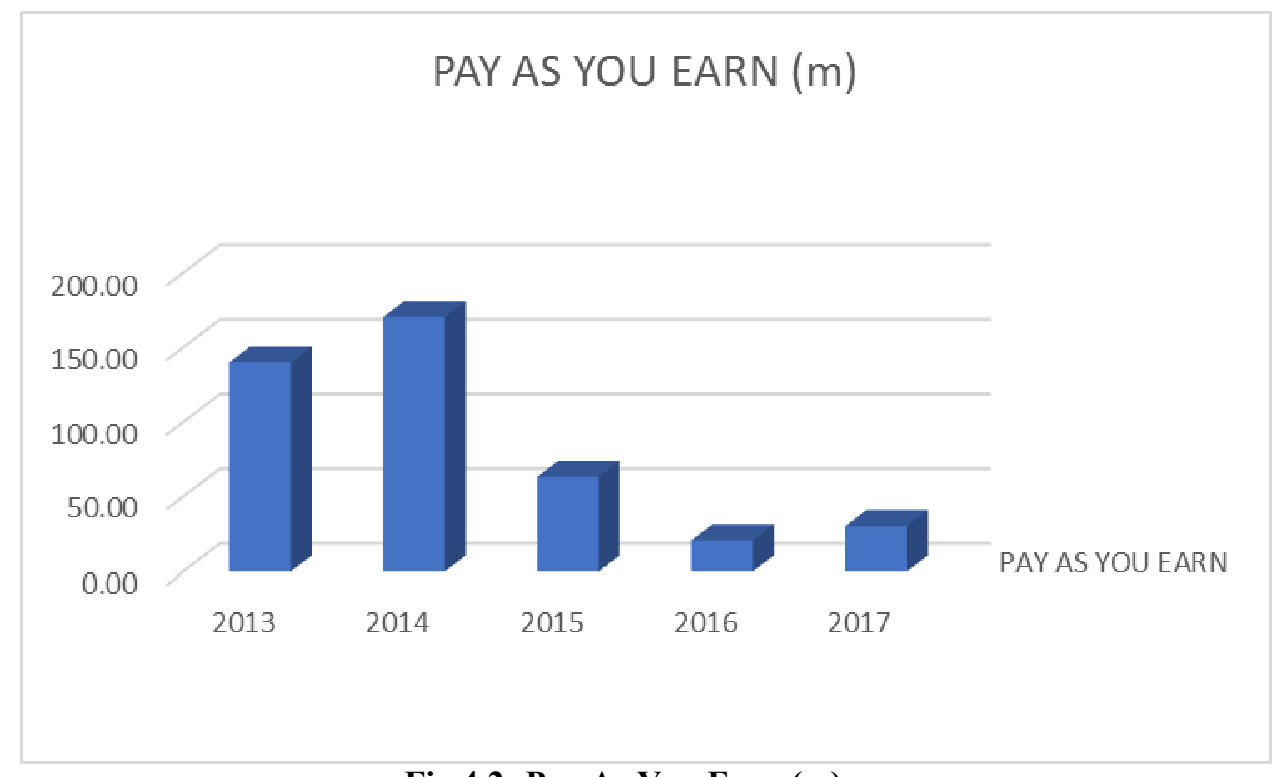

\section{Direct Assessment}

Fig 4.2: Pay As You Earn (m)

This item constitutes the second source of tax revenue to the local government as shown in Figure 4.3 and supported by Figure 4.1. There is a notable consistent pattern in its occurrence over the priod of review. This may be due to the target population for this source of revenue. They are the self-employed persons (e.g. professional contractors, traders, landlords, etc) who live permanently and derives their means of lifelihood in the environement. Revenues generated from this source ranges between $\$ 20$ million and $\$ 25$ million with the highest occuring in 2017 and the lowest in 2013.

PAYE and direct assessment combined to dominate the source of tax revenue to the local givernment. In fact, PAYE appears to be the main driver of the revenue drive. Both PAYE and total revenue follow the same path as shown in Fig 4.4.

\section{DIRECT ASSESSMENT (m)}

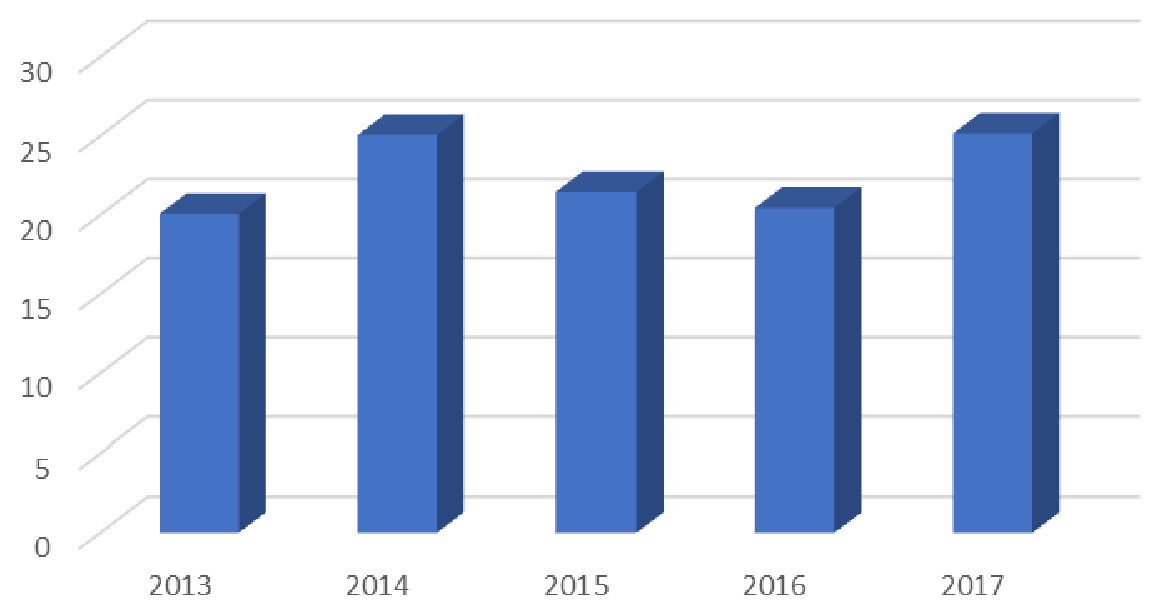

Fig 4.3: Direct Assessment (m) 


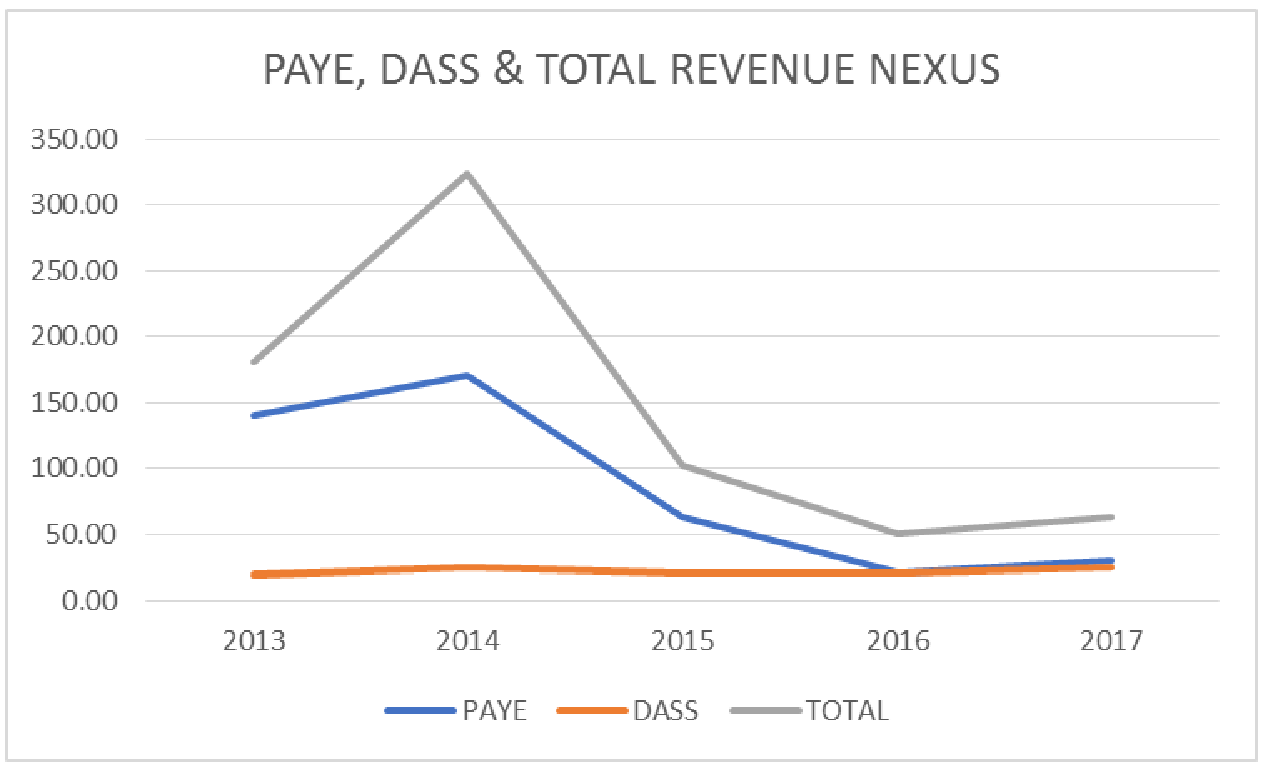

Fig 4.4: PAYE, Direct Assessment and Total Revenue Nexus

3. Development Levy

Revenue generated from development levy is very minimal over the period under review. It reached its highest level in 2014 with 993.1 thousand naira and its lowest level in 2017 of a little above 20 thousand naira. It is a very low source of tax revenue to the local government. It is shown in Fig 4.5.

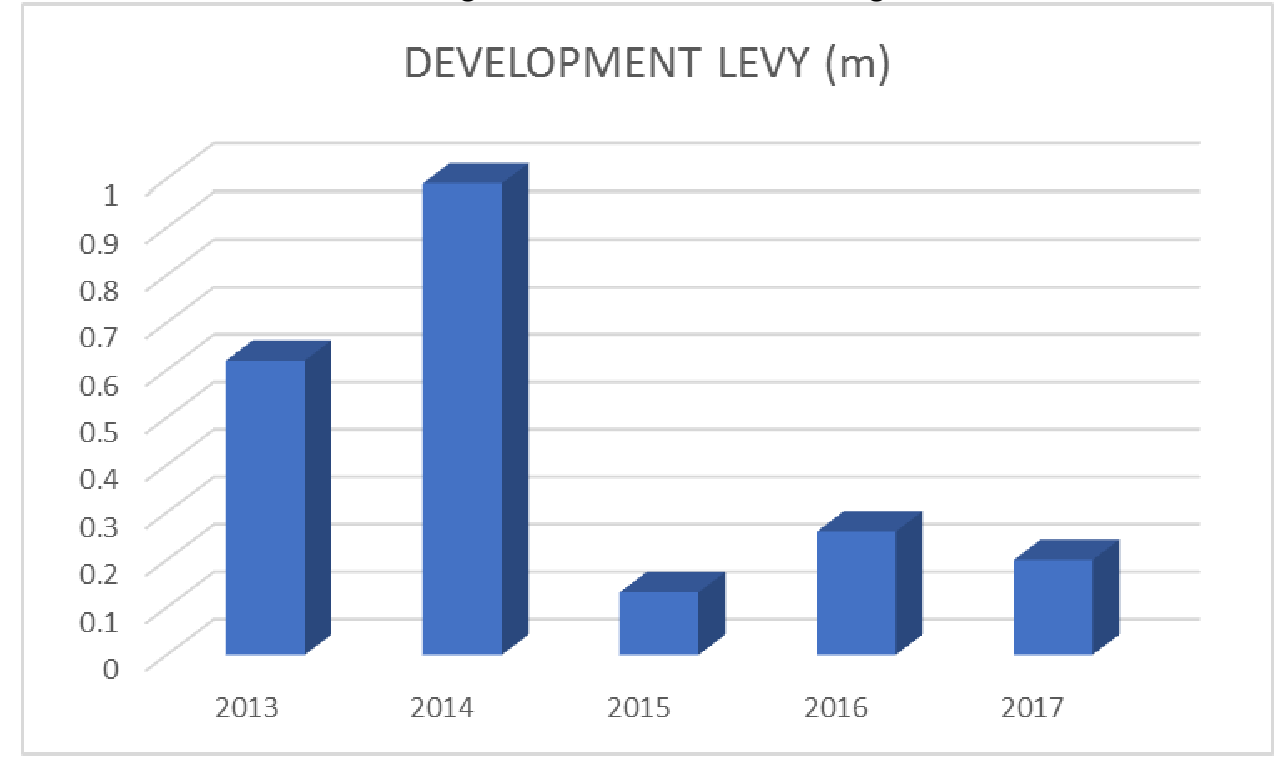

\section{Learners' Permit}

Fig 4.5: Development Levy

Learners' permit as a source of tax revenue to the local government records the lowest figure over the period of study. This is not unconnected with the target population who are the intending drivers who need a permission to learn the art of driving. This category of people may not be many in the society; this is besides the fact that the population is subject to changes over time, as whosever perfects the art of driving and subsequently obtains his valid driver's license automatically exists the group. Notably, 2013 records the highest revenue from this source, as the other years following records very low income. 


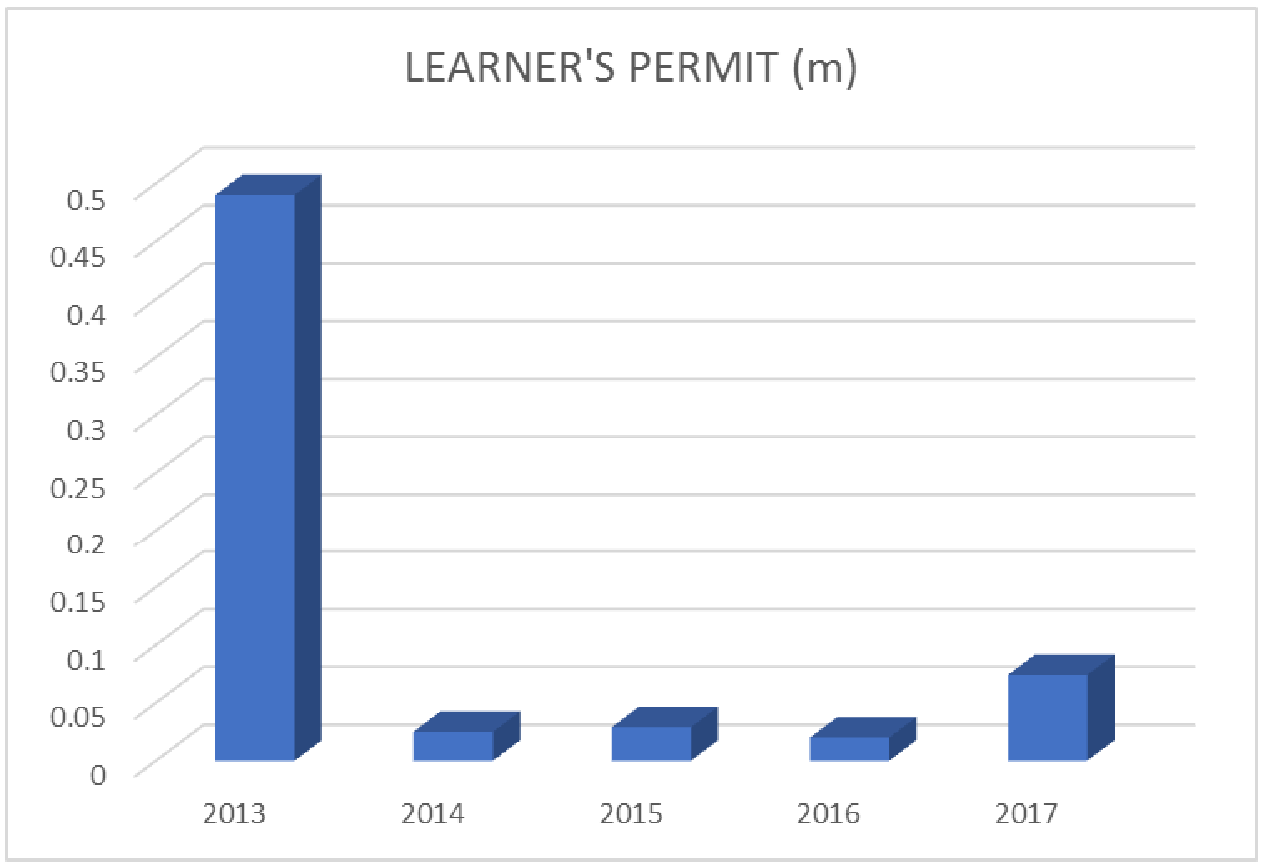

Fig 4.6: Learners' Permit (m)

Table 4.2: Correlation Matrix

Covariance Analysis: Pearson Correlation

Date: 01/05/19 Time: 10:06

Sample: 20132017

Included observations: 5

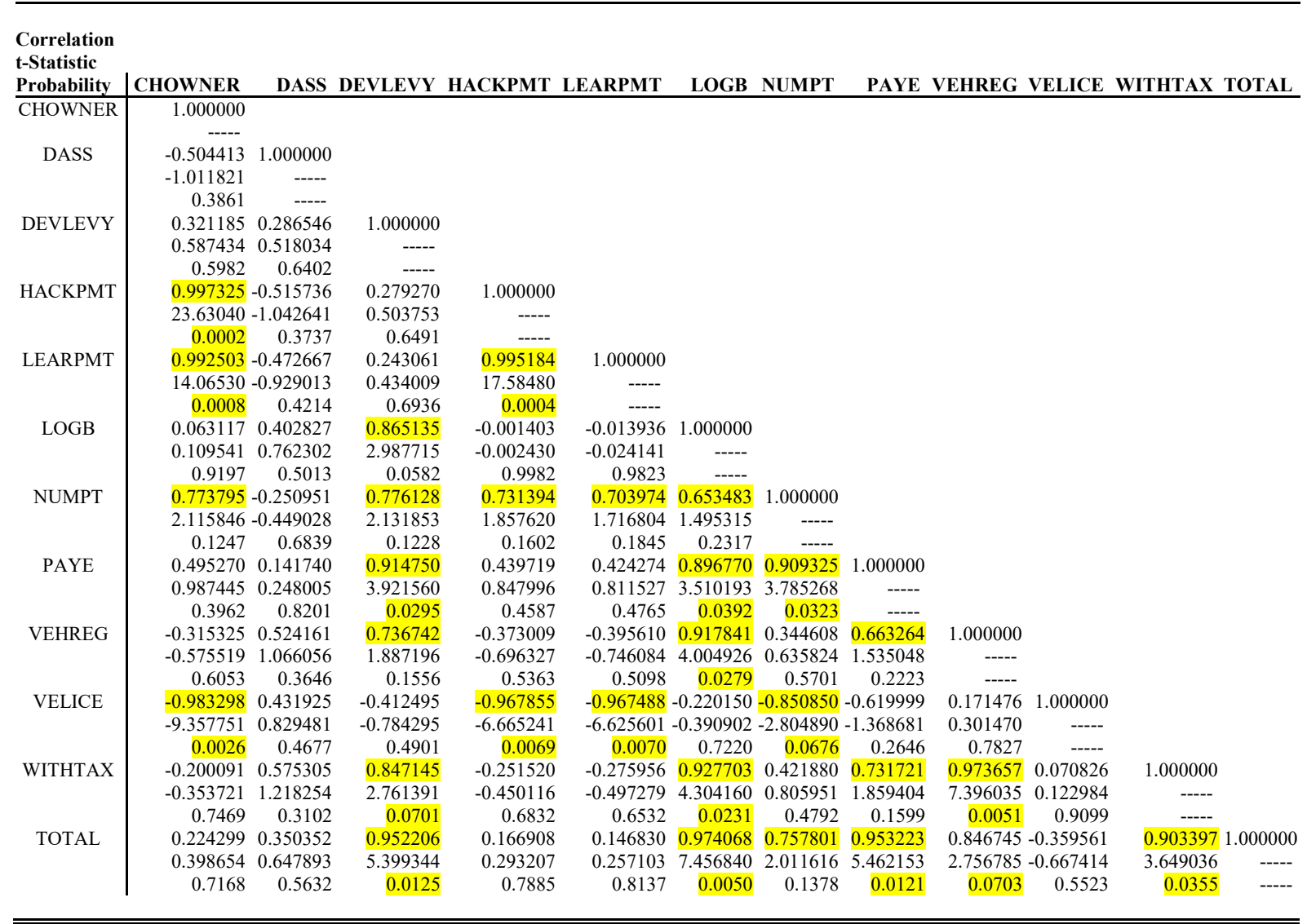

\section{Source: Researchers' Correlation Matrix}

4.2.3 Correlation Structure of the Variables

A quick interpretation of the correlation structure from Table 4.2 indicates that revenue generated through 
change of ownership is significantly highly correlated at 1 per cent with hackney permit $(t=23.63 ; p<0.01)$, learners permit $(t=14.07 ; p<0.01)$, but negatively highly correlated at 1 per cent with revenues from vehicle license permit $(t=-9.358 ; p<0.01)$; whereas it is positively but insignificantly correlated with revenues generated via number plates $(t=14.07 ; p=0.125)$. Moreover, direct assessment is insignificantly correlated with any of the nine other IGR sources in the local government. This is not unexpected because of the target population of this revenue source, who are low level self-employed persons in the economy, many of who may not own vehicles or have anything to do with transportation matters.

Development levy as a variable positively correlates significantly at 5 per cent with PAYE $(t=3.92 ; p<$ $0.05)$, at 10 per cent with vehicle $\log$ book $(t=2.99 ; p<0.1)$, but insignificantly correlates with number plates $(t$ $=2.13 ; p=0.123)$. Furthermore, hackney permit positively correlates at 1 per cent with learners' permit $(t=$ $17.58 ; p<0.05)$, negatively correlates significantly at 1 per cent with vehicle license $(t=-6.67 ; p<0.01)$, but highly insignificantly correlates with number plates $(t=14.07 ; p=0.16)$. On the other hand, PAYE significantly positively correlates at 5 per cent with three variables: direct assessment $(t=3.92 ; p<0.05)$, vehicle log book $(t$ $=3.15, p<0.05)$ and number plates $(t=3.7 ; p<0.05)$ respectively.

On the overall, all but one variable have positive correlation with the total internally generated revenue by the government for the period under review. However, only five are significant: vehicle log book at 1 per cent $(t$ $=7.46 ; p<0.01)$, PAYE at 5 per cent $(t=5.46 ; p<0.05)$, development levy at 5 per cent $(t=5.39 ; p<0.05)$, withholding tax at 5 per cent $(t=3.65 ; p<0.05)$ and vehicle registration at 10 per cent $(t=2.76 ; p<0.1)$ respectively. PAYE negatively but insignificantly correlates with vehicle license.

\subsection{Conclusion}

Tax is a major player in every society of the world. The tax system is an opportunity for government to collect additional revenue needed in discharging its pressing obligations. A tax system offers itself as one of the most effective means of mobilizing a nation's internal resources and it lends itself to creating an environment conducive to the promotion of economic growth. Taxes constitute key sources of revenue to the local government under consideration in the study. Deficiencies were noted in the tax administration and collection system thereby edging out many potential tax payers from contributing their quota to the revenue generation efforts of the local government. Those working in the informal sector of Nigerian economy do not see the need to pay tax whereas they dominate the economy. To them only, civil servants should pay tax on their earnings and this amount to over flogging the willing horse. Even revenue collection officers seem to be lenient or even connive with those in the informal sector during enforcement of tax policies. All this leads to revenue loss. There is no doubt that taxation must have affected the economic development of Nigeria in general and Local Governments in particular. Insufficient data to show that is to pay tax in the local government is the first problem that needs to be addressed as that accounted for a very high rate of evasion among the tax payers. The crude method of tax collection applied increases administrative cost hence affects the total revenue generated.

Based on the above assertion, it is recommended that:

1. Periodical training of tax officials should be introduced by the government to maintain high generation of tax revenue

2. There is the need to re-awaken the consciousness of Nigerian government and citizens on the effective use of taxation as a developmental tool.

3. Notice of tax returns at the beginning of every financial year should be supported with handbills and posters written in local languages such as Hausa, Ibo, Yoruba and others to also enable illiterates remained to alive to their civic responsibilities.

4. A good characteristic of an ideal tax system would be an emphasis on collecting small sums frequently rather than large sums infrequently from the tax-payers and heavy expenditure on collection. Tax payment should therefore meet the convenience of the taxpayers.

5. In order to enhance collection of tax, it is recommended that the local government should set up its own revenue courts. The Federal Government has set that ball rolling by setting up a federal revenue court to look into cases of tax avoidance and evasion, but its jurisdiction has not been presently extended to states and local governments.

6. The government needs a very good data base that will contain the details of the tax payers such that relationship in terms of assessment and collection will be made easy. Up till date what is obtainable in the Nigerian tax system is paper documentation that have been characterized with mutilation and falsification of figures both on the part of the tax officers and the tax payers as well.

7. The system deserves autonomy that will enable it to hire the right quality of staff and equipment that it deserves to make it function effectively.

8. Further, the little that is collected should be put into use for the benefit of the society instead of allowing it flow freely into private purses.

9. Enlightenment will make the people to know that payment of tax is a civic responsibility of every 
citizen.

10. Government should not only create an enabling environment for business establishment but also give all necessary support for its survival because profits of businesses are one of the major sources of tax revenue.

11. There should be clear cut boundaries of the tax jurisdiction of the three tiers of government without overlap to avoid multiplicity of taxes on the citizens.

\section{References}

Afuberoh, D. \& Okoye, E. (2014). The Impact of Taxation on Revenue Generation in Nigeria: A Study of Federal Capital Territory and Selected States. International Journal of Public Administration and Management Research (IJPAMR), 2(2):22-47.

Aguolu, O. (2004). Taxation and Tax Management in Nigeria, 3rd Edition, Enugu; Meridan Associates.

Akhor, S. O. (2014). Impact of Tax revenue on Economic Growth in Nigeria. (An Unpublished M.Sc. Thesis). Department of Accounting, University of Benin, Benin-City, Edo State, Nigeria

Appah, E. (2010). "The Problems of Tax Planning and Administration in Nigeria: The Federal and State.

Azaiki, M., \& Shagari, I. (2007). Oil, gas and life in Nigeria. Ibadan: Y - Books, a division of Associated Book - Makers Nigeria Limited.

Azubike, J. U. B. (2009). Challenges of Tax Authorities, Tax Payers in the Management of Tax Reform Processes.

Emmanuel, M. (2010). Nigerian tax system: Entrenching new national tax policy. Nigerian Tribune, B2- 5.

Fasina, H. T. (2014). An examination of the revenue profiles of State Governments in South Western Nigeria. International Journal of Economics, Commerce and Management, United Kingdom II (9).

Fayemi, H. (2001). Evolution of State Government in Nigeria, Journal of Nigerian Public Administration and Management. 2 (2).

IMF, (2007): IMF working paper the value-added tax: its causes and consequences prepared by Michael keen and Ben Lockwood fiscal affairs department.

Islahi, A. A. (2006) Ibn Khaldrun's Theory of Taxation and its Relevance Today, Islamic Research and Training Institute Spain. www.muslimheritage.com/default.cfm

Laffer, A. (2004). The Laffer Curve, Past Present and Future From Heritage Foundation June 9, 2011. www.heritage.org

Nzotta, S. M. (2007). Tax Evasion Problems in Nigeria: A Critique. Nigeria Account, 40(2); 40-43.

Odusola, A. (2006). "Tax Policy Reforms in Nigeria," United Nations University- World Institute for Development Economics Research (UNU-WIDER) Research Paper No.2006/03

Okafor, R. G. (2012). Tax Revenue Generation and Nigerian Economic Development, European Journal of Business and Management, 4, (19)

Olaoye, A. (2008). Tax in a borderless world. Organisation for Economic Cooperation and Development. The OECD Observer no. 257, (October 1): 10-11. http://www.proquest.com/. Accessed 24/08/ 2010.

Procter, G. (2005). State Government and Administration ${ }^{e e}$. Nigerian Government and Politics Under Military Rule, 1996-1979. London: The Macmillan Publication.

Samuel, S. E. \& Simon, S. (2011). The Effect of Income Tax on Capital Investment Decisions of Banks in Nigeria. Kogi Journal of Management, 4(1), 116-128.

Taiwo, I. O. (2008). Performance of government revenue: Achieving an optimal structure. Paper presented at the national assembly retreat on restructuring of the national budget for members of the appropriations, finance and public accounts committee, Kaduna 10-11.

Tax Justice Network [TJN) (2012). Aid, tax and finance for development.

VAIDS CTLOs Study Pack, (2017). Voluntary Assets and Income Declaration Scheme (VAIDS) in Nigeria.

Wawire, N. H. W. (2006). Determinants of Tax Revenues in Kenya, Unpublished Ph.D Thesis, Kenyatta University.

Yin, R. K. (2009). Case study research: Design and methods (4th ed.). New Delhi, India: Sage 